\section{Juventude e poder político local: a percepção e o discurso de jovens sobre as eleições municipais de 2016}

Recebido: 16.06 .17

Aprovado: 26.01 .18
Antonio Teixeira de Barros*

Resumo: $\mathrm{O}$ artigo tem como objetivo analisar o comportamento político dos eleitores jovens perante o pleito municipal de 2016 no Brasil, com base em questionário aplicado a 1.221 sujeitos, após o segundo turno das eleições. O questionário contempla aspectos como: (a) o que motiva/ desmotiva os jovens a votar para prefeito e vereador; $(b)$ quais as qualidades dos candidatos que são mais valorizadas por eles; (c) por que votam em branco ou nulo; $(d)$ o comportamento deles durante a campanha eleitoral; (e) os temas de maior interesse durante o debate eleitoral; $(f)$ as fontes de informação política mais usadas pelos informantes. Entre os resultados, destaca-se um paradoxo: os jovens manifestam insatisfação com a política e por isso votam em branco ou nulo como protesto, porém, os dados revelam motivações que se situam na esfera tradicional, como o voto em candidatos provenientes de famílias que já atuam na política local.

Palavras-chave: Sociologia política. Juventude e política. Jovens eleitores. Eleições municipais.

\section{Youth and local political power: the perception and the discourse of young people about the Brazilian municipal elections of 2016}

Abstract: The article aims to analyze the political behavior of young voters before the municipal election of 2016 in Brazil, based on a questionnaire applied with 1,221 subjects, after the second round of elections. The questionnaire includes aspects such as: (a) what motivates / discourages young people to vote for mayor and councilor; (b) what are the qualities of the candidates who are most valued by them; (c) why they vote blank or void; (d) their behavior during the election campaign; (e) the topics of greatest interest during the electoral debate; (f) the sources of political information most frequently used by informants. Among the results, a paradox stands out: young people express dissatisfaction with politics and therefore vote blank or blank as a protest, but the data reveal motivations that are in the traditional sphere, such as voting in candidates from families who already in local politics.

Keywords: Political sociology. Youth and politics. Young voters. Municipal elections.

\author{
* Antonio Teixeira de \\ Barros é doutor em \\ sociologia, docente \\ e pesquisador \\ do Programa de \\ Mestrado em Ciência \\ Política do Centro de \\ Formação da Câmara \\ dos Deputados \\ (Cefor), Brasília, \\ Distrito Federal, \\ Brasil. Orcid no 0000 \\ 0002-3061-8202. \\ <antonibarros@ \\ gmail.com>
}




\section{Introdução}

partir de uma abordagem sociológica, o artigo tem como objetivo avaliar o
comportamento político dos jovens perante as eleições municipais de 2016,
considerando que se trata do espaço da cidade onde o jovem eleitor reside e tece suas relações sociais cotidianas. Existiriam diferenças expressivas ao se tratar da relação da juventude com a política nacional e com a política na escala local? Os estudos sobre juventude e política apontam uma preferência dos jovens por seu contexto político imediato, marcado pela constituição de suas relações sociais, da construção de seus interesses e suas preferências, com as mediações das relações de reciprocidade e proximidade física e simbólica (Augusto, 2005; Augusto, 2008; Teixeira Coelho, 1997).

Ao considerar que as eleições municipais têm como foco a escolha de vereadores e prefeitos - atores por excelência da representação política local -, é oportuno, pois, avaliar o comportamento político dos jovens em pleitos municipais. Trata-se, portanto, dos agentes diretos da gestão das cidades, com sua agenda urbana que inclui o debate, a formulação, a execução e a fiscalização das políticas públicas urbanas. Estudos da ciência política mostram que a vivência democrática tem como base o âmbito local, no qual o cidadão tem suas experiências mais concretas. É na escala local que os eleitores estabelecem contatos mais próximos e diretos com as instituições políticas e seus representantes (Baquero \& Cremonese, 2009). As cidades e seus bairros constituem o espaço das dinâmicas locais de cidadania e de construção de identidades. Segundo essa ótica, o espaço urbano passa a ser concebido como estruturador da cultura, de suas dinâmicas e seus conflitos, incluindo os jovens. Trata-se de uma visão ancorada na representação da cidade como território político (Acselrad, 2011), espaço de uso coletivo, de habitação, de trânsitos e de tensões entre habitantes, lideranças políticas e outros atores locais. Por essas razões, quando se trata de estudos sobre a juventude, as relações políticas tecidas no âmbito local constituem "campo privilegiado de análise, porque nele as relações entre sociedade civil e Estado aparecem de forma mais clara" (Spósito, Silva \& Souza 2006: 239).

Como afirma Dowbor (2017: 16), "a questão do local está rapidamente emergindo para se tornar uma das questões fundamentais da nossa organização social". Isso porque o local passou a ser tratado como região de planejamento (Vainer, 2002),

compreendido não como um recorte territorial localizado e localizável, mas como um espaço com história e memória próprias, com identidades e práticas políticas determinadas, ou seja, socialmente construído (Silva, 2008: 69). 
Tal recorte, contudo,

implica uma pluralidade de poderes que se digladiam ou se associam (depende do objetivo e do momento) como os do Estado, das elites, dos micropoderes, do poder simbólico, do poder de influência etc. (Silva, 2008: 69).

O autor ressalva ainda que, para entender o local e as relações de poder nele existentes, "não basta identificá-lo ao poder político. É preciso conceituá-lo como o poder exercido econômica, social, cultural e simbolicamente" (Silva, 2008: 70). Em outras palavras, o poder local refere-se

ao conjunto de redes sociais que se articulam e se superpõem, com relações de cooperação e conflito em torno de interesses, recursos e valores, em um espaço cujo contorno é definido pela configuração desse conjunto (Fischer, 1992: 106).

No Brasil, o tema do poder local foi incorporado à agenda política, após a redemocratização,

impulsionado pelos novos atores sociais e políticos que emergiram no período, articulado aos temas da democracia, da descentralização e da participação popular (Costa, 1996: 114).

Como explica o autor, a transição democrática contribuiu para uma redefinição do estatuto das estruturas de poder local no imaginário político brasileiro. Se antes o poder local era associado a

relações coronelísticas de poder no âmbito dos pequenos e médios municípios e de relações clientelísticas e populistas nas médias e grandes cidades, [com a redemocratização,] as estruturas de poder local passaram a espaço de possibilidades de experimentos democráticos inovadores e do exercício da cidadania ativa (Costa, 1996: 113).

Nesse contexto, o poder municipal tornou-se campo privilegiado de análise porque nele

as relações entre sociedade civil e Estado, para a conformação de uma esfera pública democrática, aparecem de forma mais clara e oferecem focos importantes para a realização de pesquisas (Spósito, Silva \& Souza, 2006: 238).

Os dados foram coletados por meio de questionário eletrônico, aplicado com 1.221 jovens de 16 a 29 anos, após o segundo turno das eleições municipais. O 
período de coleta de dados durou 20 dias, de 5 a 25 de novembro do mesmo ano, por meio de questionário com perguntas fechadas e abertas, com opções excludentes e não excludentes. Aplicado no formato do Google Forms, o questionário foi divulgado nas cinco regiões geográficas do Brasil, com o auxílio de professores, pesquisadores, coletivos de jovens, escolas públicas, privadas e universidades na disseminação do link para acesso ao questionário. A divulgação se deu principalmente pelas redes sociais on-line, como Facebook e WhatsApp, as mais usadas pelo público jovem.

Os surveys eletrônicos ou websurveys constituem uma emergente modalidade de pesquisa, cuja amostragem é definida como sendo do tipo bola de neve (Dewes, 2013). A denominação se deve à difusão dos questionários pelas redes de contato dos respondentes, sendo que cada um repassa para seus amigos virtuais, e assim sucessivamente. Embora haja limitações, trata-se de um instrumento importante para o acesso a pessoas distantes, como no caso da pesquisa em questão, cujos informantes estão dispersos em todo o país (Manfreda \& Vehovar, 2002). No caso dos jovens, os websurveys se tornam um importante canal para acesso a esse público, devido à sua propensão ao maior uso de redes sociais digitais. Os jovens são considerados nativos digitais ou net generation, ou seja, já nasceram e foram socializados com o uso cotidiano das tecnologias digitais (Tapscott, 2008).

Antes da análise dos dados, o texto apresenta uma revisão bibliográfica sobre comportamento político e estudos que relacionam política e juventude.

\section{Comportamento político}

Entende-se por comportamento político o modo como o cidadão se posiciona perante o mundo político, incluindo suas motivações, percepções e atitudes (Borba, 2005; Baquero \& Cremonese, 2009; Sandoval, 1997). O tema já foi devidamente

1. Para um panorama bibliográfico sobre o tema, consultar Castro $(1992 ; 1997)$, Carreirão (2000), Radmann (2001), Borba (2005), Baquero (1997), Figueiredo (1991), Telles \& Dias (2010). discutido, com revisões de literatura amplamente conhecidas ${ }^{1}$. Esses estudos destacam entre as principais correntes explicativas a perspectiva sociológica, a psicológica e a teoria da escolha racional. A primeira aborda as condições sociais da decisão do voto e o contexto no qual as preferências se formam, além da conjuntura socioeconômica e a cultura política; a segunda busca apreender o comportamento político a partir das motivações, percepções e atitudes dos indivíduos em relação ao mundo político; a terceira considera a decisão do voto

como produto de uma ação racional individual orientada por cálculos de interesse, que levam o eleitor a se comportar em relação ao voto como um consumidor no mercado (Borba, 2005: 157). 
Por comportamento eleitoral entende-se "o processo de formação e de expressão das preferências individuais em ordem às alternativas políticas sujeitas à crítica do voto" (Fisichiella, 1992: 189). A literatura registra duas possibilidades de estudar o comportamento eleitoral: de forma agregada e individual. A primeira refere-se ao comportamento de determinados grupos, como moradores de um bairro ou os operários de uma certa região, por exemplo. A segunda diz respeito ao indivíduo separadamente. Trata-se, neste caso, de reconhecer a percepção subjetiva como elemento constitutivo do comportamento eleitoral (Fisichiella, 1992). As pesquisas consideram ainda duas formas de se observar e estudar o comportamento eleitoral: a expressão do voto e a abstenção eleitoral. Afinal, "a abstenção exprime uma determinada opção política e uma orientação de consciente hostilidade contra o regime vigente" (Fisichiella, 1992: 192). A abstenção, como resultado da apatia política, no caso dos jovens, "não é tanto desinteresse, mas recusa". Em outras palavras,

desertando das urnas, exprimem o sentimento de vacuidade e de inutilidade da própria participação: vote ou não [...] o sistema continuará a funcionar da mesma maneira (Fisichiella, 1992: 192).

A literatura internacional sobre comportamento político registra que a faixa etária é uma variável de grande relevância quando se trata de interesse por política e formas de participação, com base no argumento de os recursos materiais se acumularem no decorrer do tempo. Assim, o jovem se interessaria menos por política, mas, conforme adquire maiores níveis educacionais, amplia o seu interesse quando adulto e se desinteressa na terceira idade devido à perda de seus vínculos sociais. Trata-se do que Milbrath e Goel (1977) denominam o "efeito curvilíneo" entre interesse por política e idade.

O componente geracional, portanto, revela-se uma variável relevante no contexto recente. Por outro lado, cabe considerar a necessidade de estudos empíricos que confirmem a tendência apontada no cenário brasileiro, uma vez que dados coletados a partir dos levantamentos do Latinobarômetro mostrarem que ainda temos percentuais e padrões "muito semelhantes entre os estratos etários" (Ribeiro, 2012: $30)^{2}$, diferentemente do que mostram estudos empíricos estrangeiros. Tal constatação leva ao questionamento acerca da emergência de uma cidadania mais crítica e contestatória entre os jovens brasileiros:

Apesar de pesquisadores apresentarem evidências consistentes sobre uma mudança geracional no padrão de participação em algumas democracias consolidadas, esse não é um fenômeno verificável entre o público brasileiro. [...] não foram encontradas

2. Uma das razões dessa semelhança certamente está na obrigatoriedade do voto a partir dos 18 anos, o que não ocorre em todos os países mencionados pelo autor 
diferenças importantes, o que nos leva à conclusão de que não podemos falar de uma juventude mais crítica em relação às formas convencionais de envolvimento ou mais engajada em modalidades ligadas ao protesto político (Ribeiro, 2012: 33).

Outra observação relevante sob a ótica geracional é o potencial de novidade e de criatividade que é inerente aos jovens, uma vez que eles "se constituem enquanto novidade histórica" em relação às demais gerações e

às tradições culturais que se pretendem hegemônicas, pois enquanto nova geração a juventude está fora da lógica estruturante do mundo já instituído (Zitkoski \& Hammes, 2014: 136).

Além disso, como enfatiza Mische (1997), cada vez mais os jovens se alinham a projetos que valorizam o protagonismo de suas identidades. Em razão disso, rejeitam modelos cristalizados e tentam construir novas convergências e novos padrões de comportamento.

Nessa perspectiva, conforme argumenta a autora citada, é necessário considerar os contextos relacionais vinculados ao campo experiencial dos "mundos juvenis" historicamente situados. Outro aspecto relevante é a análise do papel dos grupos organizados, que funcionam de forma ambígua e contraditória, ora como obstáculo, ora como "pontes articuladoras" para a construção de novos projetos de participação política das juventudes (Mische, 1997: 145), com foco na experiência do presente.

Castro e Mattos (2009) avaliam que o comportamento político da juventude se caracteriza pela oscilação entre o idealismo e o pragmatismo ou pela combinação de ambos. O idealismo se expressa "pelo desejo de mudar o mundo, a cidade, ou a escola, e de criar uma sociedade solidária" (Castro \& Mattos, 2009: 809). No caso do pragmatismo, explicam as autoras, a identificação com o campo da política "ancora-se na possibilidade de agir no presente", ou seja,

a sensação de ser útil e de poder ser um agente transformador da sociedade relaciona-se com as possibilidades de ação que os jovens vislumbram nos movimentos políticos organizados (Castro \& Mattos, 2009: 808).

Seja pelo idealismo, seja pelo pragmatismo, o foco do discurso dos jovens seria a ação política. Na visão das pesquisadoras:

Ressaltamos que para os jovens a ação assume uma dimensão supervalorizada, já que é ela, justamente, que thes confere expres- 
são singular como sujeitos no mundo comum. Agir significa não apenas fazer, mas também ser. Assim, a ação política é vista pelos jovens como uma via para se sentirem "reais" [...], como uma forma de contrariarem o sentimento recorrente de que as suas vidas carecem de consistência, uma vez que tudo nelas remete ou para o passado, quando eram ainda crianças, ou para um futuro incerto, para um tempo em que se tornarão adultos (Castro \& Mattos, 2009: 812).

As visões sobre política que servem de substrato para o engajamento juvenil impulsionadas pelo idealismo, conforme registra Castro (2008), são marcadas pela convergência na defesa de causas comuns, independentemente da orientação ideológico-partidária. Essa convergência é expressa, por exemplo, no combate à corrupção, à redução das desigualdades sociais e na reivindicação de melhores serviços públicos, especialmente educação e saúde. Isso significa que a militância juvenil nos partidos políticos e nos movimentos estudantis é pautada por uma visão crítica da sociedade e pela participação entendida como forma de promover uma ampla transformação social (Castro, 2008: 257).

Segundo Florentino (2008), um aspecto importante nesse debate é o enfoque geracional, com duas visões em disputa.

[A primeira], geralmente mais tradicional, da juventude como responsável pela reprodução da herança cultural de uma sociedade, e aí a preocupação com suas posturas de cunho político, para que ocorram dentro de um padrão esperado. [A segunda apresenta a juventude como] a energia revitalizante de uma sociedade, [...] tem a responsabilidade não de reproduzir, mas de questionar e transformar algumas condições sociais de seu grupo (Florentino, 2008: 209).

\section{Juventude e política}

Estudos sobre os padrões de engajamento político da juventude revelam duas grandes tendências. A primeira consiste no baixo engajamento institucional e a segunda na afinidade dos jovens com novas e emergentes formas de participação política (Boghossian \& Minayo, 2009). Em relação a essa constatação, Augusto (2008: 164) complementa que os jovens tendem a olhar a política como "o que acontece no parlamento" e não tanto como "algo que afeta minha vida". Segundo o autor, uma das chaves analíticas para a compreensão da escassa relação dos jovens com a política institucional e seu fraco envolvimento nos sistemas democráticos formais está nas rígidas estruturas estatais. Para o autor, não se trata de apatia, mas de 
um modo próprio de a juventude se relacionar com os processos democráticos. Desse diagnóstico é que resultariam as crescentes incoerências entre os modelos institucionalizados de ação política e as práticas sociais, revelando que o poder que as instituições dispõem para dar sentido às biografias individuais está em declínio. Para o autor,

\begin{abstract}
a proposta é que o aparente alheamento dos jovens relativamente à política "do palácio" reflete, não um apoliticismo, mas um desencantamento/desconfiança relativamente aos mecanismos formais ou convencionais de integração política, que poderá resultar numa desinstitucionalização da ação política juvenil (Augusto, 2008: 161).
\end{abstract}

Nesse processo, segundo o autor, é necessária a ressalva de que os jovens têm se afastado da política institucionalizada, mas não da democracia. Para os jovens, a democracia surge associada a um desejo de liberdade e autonomia. Por outro lado, o autor salienta que a democracia está mais estreitamente vinculada ao plano existencial dos jovens e não ao plano político. Assim, é necessário

não confundir desinteresse pela política com desinteresse pelos mecanismos formais e institucionais da política, em particular os partidos e as elites que as lideram (Augusto, 2008: 164).

A particularidade no modo juvenil de interpretar e encarar a participação é um dos fatores que explicam a suspeita deles em relação à política institucionalizada, com opiniões desfavoráveis e marcadas pela desconfiança. Além disso, as disputas, os debates e conflitos característicos da esfera partidária, por exemplo, são vistos como impedimentos para o engajamento e a participação no plano institucional, pois implica negociatas e acordos suspeitos. Tais arranjos são considerados instrumentos para a máquina partidária, algo que se distancia do ideal da transformação sociopolítica almejada. Por essa razão, os jovens preferem

uma via direta de ação e de participação na sociedade, em que podem constatar, por eles mesmos, os efeitos do que fazem, sem intermediações (Castro, 2008: 263).

Os estudos sobre política e juventude registram um refluxo nas formas convencionais de participação política entre os jovens e um crescimento na adesão às modalidades de mobilização caracterizadas pela contestação, pelo protesto e ativismo (Ribeiro, 2012). As práticas políticas estabelecidas são nitidamente rechaçadas pelos movimentos protagonizados por jovens, levando-os a negar que fazem política, 
mesmo quando existem características tipicamente políticas, como mostra o levantamento coordenado por Mayorga, Castro e Prado (2012). Isso implica a adesão a um enquadramento interpretativo de rejeição à política partidária e às lógicas dominantes nas eleições e no cotidiano das câmaras de vereadores, assembleias legislativas, Câmara dos Deputados e Senado Federal.

O reflexo direto disso é a baixa confiança nas instituições legislativas, com registro de 4,4 numa escala de zero a 10 (Baptista et alii, 2013: 129). O que explica tal desempenho em termos de confiança no Poder Legislativo (em todos os níveis), segundo os autores citados, é a recorrente associação entre política e corrupção, o que reforça o pessimismo e a descrença da juventude (Telles \& Dias, 2010). Esses estudos sugerem que

não são os jovens que desconhecem a relevância da política, mas antes a forma predominante de se fazer política no país não os reconhece como interlocutores, gerando em muitos deles indiferença ou aversão (Abramo \& Venturi, 2000: 5).

Segundo Pierre Bourdieu, a idade é um dado biológico socialmente manipulado e manipulável e que o fato de

falar dos jovens como se fossem uma unidade social, um grupo constituído, dotado de interesses comuns, e se relacionar estes interesses a uma idade definida biologicamente já constitui uma manipulação evidente (Bourdieu, 1983: 112) ${ }^{3}$.

O fato é que a complexidade envolvida na definição da categoria juventude inclui pelo menos três aspectos cruciais, conforme Marialice Forachi (1965: 302). O primeiro refere-se ao reconhecimento de que "se trata de uma fase da vida"; o segundo incorpora "a constatação de sua existência como força social renovadora"; e o terceiro é calcado na percepção de que a juventude "vai muito além de uma etapa cronológica, para constituir um estilo próprio de existência e de realização do destino pessoal".

O conceito de geração é central na sociologia da juventude, desde os estudos pioneiros de Karl Mannheim (1968), entendido como além da faixa etária, ou seja, no sentido de compartilhamento de determinadas experiências de vida, de construção de referências socioculturais, algo próximo do sentido filosófico de "espírito do tempo" (Enne, 2011). Cabe ressaltar que o argumento de Mannheim - de a simples coexistência no mundo, no sentido cronológico - não pode ser considerado fator decisivo para assegurar que um grupo faça parte da mesma geração. Além disso, o

3. Acerca dessa discussão, cabe ressaltar o registro de Pereira (2007: 3), acerca da antropologia das idades, segundo a qual "a idade é considerada, junto com o sexo, um princípio de organização social universal". 
4. Ao mesmo tempo em que impera essa visão plural da juventude, a autora alerta: "observa-se uma uniformização da ideia de juventude, considerando-a indistintamente como um grupo único, para o qual se lança o olhar como 'problema político' necessitando de intervenção e de controle" (Malfitano, 2011: 525).

autor argumenta que, politicamente, "a juventude não é progressista nem conservadora por índole, porém, é uma potencialidade pronta para qualquer nova oportunidade" (Mannheim, 1968: 73).

O autor chama atenção para a multiplicidade de fatores que condicionam as experiências sociais dos jovens, como é próprio da vida social. No contexto atual, é necessário considerar, por exemplo,

a classe social de sua família, se sua moradia é em área rural ou urbana, se pertence ou não a grupos étnicos marginalizados, seu gênero, opção religiosa, dentre tantos outros recortes possíveis (Florentino, 2009: 217).

Em outras palavras, embora a juventude seja representada sociologicamente como "uma categoria relacional que posiciona os indivíduos como pertencente a uma dada faixa etária" (Gohn, 2013: 205), o que as pesquisas recentes mostram é que existem várias juventudes. Cada vez mais os jovens passam a ser caracterizados como um grupo social plural e emergente (Malfitano, 2011) ${ }^{4}$, com diferentes formas de engajamento, participação e opinião, variados repertórios de ação coletiva e múltiplas agendas (Dayrell; Moreira \& Stengel, 2011), o que requer olhares menos simplificadores. Isso dificulta a identificação de um padrão de engajamento, de julgamento e de participação, além de apontar para a dificuldade de se registrar tendências uniformes e estanques de opinião (Ribeiro, Lanes \& Carrano, 2006).

\section{Análise dos dados}

TABELA 1

PERFIL DOS RESPONDENTES

\begin{tabular}{|r|l|r|r|}
\hline \multicolumn{1}{|c|}{ Sexo } & \multicolumn{1}{c|}{ N } & \multicolumn{1}{c|}{$\%$} \\
\hline & Feminino & 619 & 50,70 \\
\hline \multicolumn{4}{|c|}{ Escolaridade } \\
\hline & Masculino & 49,30 \\
\hline & Ensino médio completo & 321 & 26,29 \\
\hline & Ensino médio incompleto & 271 & 22,19 \\
\hline & Curso superior incompleto & 191 & 15,64 \\
\hline & Curso superior completo & 159 & 13,02 \\
\hline & Ensino fundamental completo & 136 & 11,14 \\
\hline & Pós-graduação incompleta & 112 & 9,17 \\
\hline & Pós-graduação completa & 31 & 2,54 \\
\hline
\end{tabular}

O perfil dos respondentes mostra equilíbrio entre homens e mulheres, com $50,70 \%$ do sexo feminino e $49,30 \%$ do sexo masculino, como se observa na Tabela 1. Quanto à escolaridade, predominam os que estão no ensino médio (completo e incompleto somam 48,48\%), seguido do curso superior (completo e incompleto somam $28,66 \%)$. Em relação à cor, predominam os pardos e brancos, com $40,36 \%$ e $28,34 \%$, respectivamente. Os três níveis de faixa etária estão bem representados, cada um com aproximadamente 
um terço da amostra. As principais religiões estão representadas, mas os não religiosos predominam $(32,51 \%)$.

Quanto à região geográfica, prevalecem os residentes no Sudeste (33,33\%), Nordeste $(28,01 \%)$ e Sul $(21,46 \%)$, exatamente as mais populosas do Brasil. Os residentes em regiões metropolitanas e capitais estão em maioria, com 40,70\% e $33,82 \%)$, respectivamente. Quanto à renda familiar, os segmentos mais expressivos encontram-se na escala de dois a sete salários mínimos (72,26\%). Os jovens filiados a partidos políticos são minoria (6,39\%), mas há um expressivo número de simpatizantes de partidos (51,35\%).

Entre os filiados, a maior quantidade mencionou o PT $(35,90 \%)$, o PV $(23,08 \%)$ e o PSOL $(15,36)$, considerados partidos de esquerda. No espectro da direita aparece o PSDB, com 10,26\% (Tabela 2). Os dados confirmam duas tendências identificadas em pesquisas recentes sobre a preferência dos jovens em relação aos partidos políticos. A primeira diz respeito à maior afinidade com os partidos de esquerda e a segunda refere-se ao crescimento do PSDB em segmentos juvenis das classes médias (Hori, 2016; Galhardi, 2015).

Apesar da crise de reputação do PT, devido às denúncias e prisões de expoentes da legenda desde o escândalo do mensalão, o Partido dos Trabalhadores ainda mantém uma militância jovem expressiva, apesar de começar a perder a simpatia de alguns segmentos juvenis para o PSDB. Conforme revela Galhar-

\begin{tabular}{|c|c|c|c|}
\hline \multirow[t]{2}{*}{3} & \multicolumn{2}{|l|}{ Cor / Etnia } & \multirow[b]{2}{*}{40,36} \\
\hline & Pardo & 493 & \\
\hline & Branco & 346 & 28,34 \\
\hline & Asiático & 129 & 10,57 \\
\hline & Negro & 127 & 10,40 \\
\hline & Indígena & 118 & 9,66 \\
\hline & Não informado & 8 & 0,66 \\
\hline 4 & Faixa etária & & \\
\hline & 20 a 24 anos & 398 & 35,50 \\
\hline & 25 a 29 anos & 381 & 33,99 \\
\hline & 16 a 19 anos & 342 & 30,51 \\
\hline & Religião & & \\
\hline & Não sou religioso & 397 & 32,51 \\
\hline & Católico & 249 & 20,39 \\
\hline & Evangélico & 242 & 19,82 \\
\hline & Espírita & 129 & 10,57 \\
\hline & Religiões orientais & 118 & 9,66 \\
\hline & Religiões de matriz africana & 72 & 5,90 \\
\hline & Outras & 14 & 1,15 \\
\hline \multirow[t]{6}{*}{5} & \multicolumn{2}{|l|}{ Região } & \\
\hline & Sudeste & 407 & 33,33 \\
\hline & Nordeste & 342 & 28,01 \\
\hline & Sul & 262 & 21,46 \\
\hline & Centro-Oeste & 107 & 8,76 \\
\hline & Norte & 103 & 8,44 \\
\hline \multirow[t]{5}{*}{6} & \multicolumn{2}{|l|}{ Local de residência } & \\
\hline & Região metropolitana & 497 & 40,70 \\
\hline & Capital & 413 & 33,82 \\
\hline & Cidade do interior & 231 & 18,92 \\
\hline & Povoado & 80 & 6,55 \\
\hline \multirow[t]{7}{*}{7} & Renda familiar & & \\
\hline & Dois a quatro salários mínimos & 431 & 38,45 \\
\hline & Cinco a sete salários mínimos & 379 & 33,81 \\
\hline & Oito a dez salários mínimos & 128 & 11,42 \\
\hline & Acima de dez salários mínimos & 92 & 8,21 \\
\hline & Até um salário mínimo & 79 & 7,05 \\
\hline & Não informado & 12 & 1,07 \\
\hline \multirow[t]{5}{*}{8} & Filiação partidária & & \\
\hline & Simpatizante mas não filiado & 627 & 51,35 \\
\hline & Não filiado & 516 & 42,26 \\
\hline & Filiado & 78 & 6,39 \\
\hline & Total & 1.221 & \\
\hline
\end{tabular}

Fonte: Elaboração própria. 
TABELA 2

PARTIDOS POLÍTICOS

DOS RESPONDENTES FILIADOS

\begin{tabular}{|l|c|c|}
\hline \multicolumn{1}{|c|}{ Partidos } & \multicolumn{1}{c|}{ N } & $\%$ \\
\hline PT & 28 & 35,90 \\
\hline PV & 18 & 23,08 \\
\hline Psol & 12 & 15,38 \\
\hline PSDB & 8 & 10,26 \\
\hline PCdoB & 6 & 7,69 \\
\hline Rede & 6 & 7,69 \\
\hline Total & 78 & 100,00 \\
\hline
\end{tabular}

Fonte: Elaboração própria.

di (2015), pela primeira vez, o PT foi ultrapassado pelo PSDB, em 2015. A pesquisa do autor mostra que $6 \%$ preferem os tucanos e $5 \%$ os petistas. Em 2014, os petistas contavam com $15 \%$ de simpatia dos jovens, enquanto os tucanos $5 \%$. Apesar disso, a preferência dos jovens pelos partidos de esquerda se mantém porque a maioria "confia ser mais viável sanear a esquerda do que entregar o poder à direita" (Hori, 2016).

A Tabela 3 mostra que 25,47\% dos jovens votaram para os dois cargos (prefeito e vereador). Os que não votaram somam $10,89 \%$ e os que justificaram a ausência são $1,73 \%$. Há uma variedade de outras alternativas, as quais são explicadas pelos próprios jovens, por meio de seus relatos no questionário. Em suma, apenas 25,47\% declaram o voto pleno, sem nenhum tipo de abstenção (nos dois cargos, já que se trata de um pleito municipal em que ambos os cargos são relevantes). Somadas as alternativas de votos válidos chegamos ao total de 45,20\%. O ato de não votar é aparentemente muito baixo (apenas 12,61\% somando abstenção com justificativa de ausência). Entretanto, considerando os votos brancos e nulos, o percentual de votos não aproveitados é muito elevado, chegando a 42,17\%. Somados com a abstenção e a justificativa de ausência temos um percentual de 54,80\%.

Convém aqui mencionar que as abstenções, votos brancos e nulos superaram o número de votos obtidos por candidatos eleitos em 22 cidades, sendo dez capitais, como Rio de Janeiro, Belo Horizonte, Curitiba, Porto Alegre, Aracaju, Campo Grande, Cuiabá, Belém e Porto Velho (Esposito \& Lourenço, 2016). O total de abstenções, brancos e nulos no primeiro turno foi de $30,76 \%$ e ainda maior no segundo turno: 34,73\% (TSE, 2016). Esses dados chamam a atenção para a tendência de redução da participação eleitoral, até mesmo nos países em que o voto é obri- 
gatório, como no Brasil, fruto da desconfiança política, especialmente no caso da juventude (Costa, 2016).

Antes de prosseguir, cabe esclarecer que o questionário aplicado continha questões fechadas e abertas, com o propósito de oferecer oportunidade aos jovens de se expressarem sobre as questões a eles postas e não simplesmente marcarem as opções que resultariam na quantificação das respostas sob a forma de tabelas e gráficos. Houve elevado interesse dos jovens em escrever, com mais de $40 \%$ na forma de respostas abertas. Em razão disso e pela impossibilidade de utilizar todos os depoimentos no corpo do texto, optamos pela sistematização das respostas subjetivas segundo a técnica da análise de conteúdo (Bardin, 2009). Essa técnica consiste em agrupar visões similares sobre um mesmo assunto em argumentos-chave, por afinidade ou similaridade semântica, mesmo quando expressos em outras palavras.

Ainda sobre os dados do Tabela 3, o voto em branco para ambos os cargos (10,90\%) foi explicado pelos jovens, em 78\% dos casos, como "falta de opção", ou seja, nenhum dos candidatos agradou aos jovens eleitores. "Para mim, todos eram iguais, então, diante da falta de boas alternativas, preferi votar em branco", relatou um dos respondentes. Essa mesma justificativa se repetiu dezenas de vezes, embora escrito com palavras diferentes. Outros explicaram que faltava maturidade para escolher, em menor proporção (cerca de 8\%). "Votar é algo sério demais, então eu preferi votar em branco porque ainda não me sinto pronto para tomar uma decisão dessas". Essa é foi a justificativa mais citada 5 .

O voto nulo, na maioria dos casos, foi considerado pelos respondentes como "voto de protesto", com mais de $90 \%$ das menções nos comentários escritos no questionário. Um enunciado que expressa essa visão dos jovens é o seguinte:

Já que o voto é obrigatório, eu compareço, mas muito de contravontade (sic). Por isso, anulo o voto, pois a política é uma vergonha, um caso perdido.

Os que não votaram também apresentaram um discurso similar, alegando motivos de ordem ética e moral:

Não quero compactuar com essa bandalheira, por isso nem sequer fui votar. É mais fácil depois ir no TRE e pagar a multa. Não quero perder meu tempo com uma eleição em que só tem candidato desqualificado e partidos comprometidos com a corrupção e a desonestidade.

5. A maioria (cerca de 85\%) apontou apenas um argumento, mas houve registros de casos com mais de uma justificativa. 
TABELA 4

O QUE TEVE MAIS PESO NA SUA ESCOLHA PARA VEREADOR?

\begin{tabular}{|l|c|c|}
\hline \multicolumn{1}{|c|}{ Fatores } & 342 & 28,01 \\
\hline Candidato sem envolvimento em denúncias judiciais & 201 & 16,46 \\
\hline A personalidade e o caráter do candidato & 164 & 13,43 \\
\hline Os apoiadores locais do candidato & 146 & 11,96 \\
\hline A família do candidato e seus parentes que já estão na política & 97 & 7,94 \\
\hline Candidato filho ou parente de políticos famosos da sua região & 72 & 5,90 \\
\hline Candidato vinculado a sindicatos e movimentos sociais & 71 & 5,81 \\
\hline O histórico político do candidato & 52 & 4,26 \\
\hline As propostas escritas do candidato & 44 & 3,60 \\
\hline O partido do candidato & 22 & 1,80 \\
\hline Candidato religioso (católico ou evangélico) & 8 & 0,66 \\
\hline O fato de o(a) candidato(a) ser jovem & 2 & 0,16 \\
\hline Outros fatores & 1.221 & 100,00 \\
\hline Total & & \\
\hline
\end{tabular}

Fonte: Elaboração própria.

TABELA 5

O QUE TEVE MAIS PESO NA SUA ESCOLHA PARA PREFEITO?

\begin{tabular}{|l|c|c|}
\hline \multicolumn{1}{|c|}{ Fatores } & N & $\%$ \\
\hline Candidato sem envolvimento em denúncias judiciais & 326 & 26,70 \\
\hline A personalidade e o caráter do candidato & 187 & 15,32 \\
\hline Os apoiadores locais do candidato & 141 & 11,55 \\
\hline A família do candidato e seus parentes que já estão na política & 129 & 10,57 \\
\hline Candidato filho ou parente de políticos famosos da sua região & 111 & 9,09 \\
\hline Candidato vinculado a sindicatos e movimentos sociais & 109 & 8,93 \\
\hline O histórico político do candidato & 102 & 8,35 \\
\hline As propostas escritas do candidato & 59 & 4,83 \\
\hline O partido do candidato & 21 & 1,72 \\
\hline Candidato religioso (católico ou evangélico) & 20 & 1,64 \\
\hline O fato de o(a) candidato(a) ser jovem & 12 & 0,98 \\
\hline Outros fatores & 4 & 0,33 \\
\hline Total & 1221 & 100,00 \\
\hline
\end{tabular}

Fonte: Elaboração própria.

Entre os motivos que levaram alguns a votarem somente para um cargo (prefeito ou vereador) estão razões subjetivas, como "consideração pelo candidato" e "respeito pela família do candidato": "Eu só votei porque conheço o candidato há muito tempo, tenho respeito e consideração por ele e a família dele". Outro escreveu que "votei porque, nesse mar de lama, o candidato é uma exceção, pois sempre foi honesto e trabalhador, sem envolvimento na corrupção". 
Ao serem indagados sobre o que teve mais peso em suas escolhas eleitorais, as razões são similares, tanto na eleição para o cargo de prefeito como de vereador, conforme mostram as Tabelas 4 e 5. Em ambos os casos se destacam os candidatos sem envolvimento em denúncias judiciais (26,70\% e 25,06\%). A personalidade e o caráter do candidato vêm na sequência (15,32\% e 12,86\%). Os apoiadores locais aparecem em terceiro lugar (11,55\% e 12,20\%). Nas respostas abertas, os jovens justificaram essa escolha, como sendo

muito importante saber quem está ao lado do candidato, quem Ihe dá apoio político, pois sabemos que um vereador ou um prefeito sem apoio de políticos importantes em Brasília ou nos escaIões políticos mais elevados não terá como executar seus projetos políticos. A política tem como base as coligações e os acordos, o município não é uma ilha separada dos escalões superiores da política.

A família do candidato também é um fator relevante para justificar a escolha dos jovens (10,73\% e 10,57\%). Esse dado mostra que os jovens preferem votar em candidatos que fazem parte de uma família de políticos:

Prefiro votar em alguém de uma família que já tem tradição na política, pois passa mais confiança, ao contrário de um candidato aventureiro que a gente não sabe de onde veio.

Outro respondente escreveu: "Política é tradição e o nome da família é importante, pois ele não vai querer fazer algo errado para comprometer a família dele toda". Esses dados e os depoimentos, de certa forma, contrariam a literatura que ressalta a associação da juventude com a renovação política, com a transformação social e termos similares.

Em relação à expressiva valorização dos jovens aos apoiadores locais dos candidatos, cabe destacar que as redes políticas locais, tecidas e construídas com base no capital social, nas relações de reciprocidades, favores e campos de ajuda não passam despercebidas pelos jovens eleitores (Barreira \& Barreira, 2012: 307). Segundo os autores, isso significa que as percepções de eleitores no âmbito de pleitos locais "contemplam sentidos de pertencimento, reconhecimento e avaliações morais que emergem em uma situação de concorrência dos candidatos". Na mesma linha de raciocínio,

[...] trata-se de registrar a existência de uma economia simbólica formada de práticas e percepções que influenciam a adesão a candidatos, construída mais no campo das dádivas que no âmbito do direito. A troca de dádiva e seus limites, os sentidos de pertenci- 
mento e reconhecimento e a lógica paradoxal do interesse versus desinteresse fornecem embasamentos teóricos relevantes para explicar a busca de adesão de candidaturas, os sentidos de representação política e as transações estabelecidas em torno do voto (Barreira \& Barreira, 2012: 307).

Essas redes se fortalecem ainda mais durante as campanhas eleitorais, pois "parentes e padrinhos fortes garantem mais recursos para a campanha de candidatos" (Salvador, 2016). Em suma, além do capital das relações políticas familiares se constituir em uma das principais de formas de ampliação do capital político e eleitoral no Brasil (Miguel, 2003), as redes simbólicas resultantes do capital de reputação dos apoiadores locais são percebidas pelos eleitores jovens como fator que aumenta as credenciais políticas e morais dos candidatos que contam com esses suportes políticos. A pesquisa com os jovens mostra o quanto ainda existem razões motivadas pela gramática da política local (Martins, 2003; Barreira, 1996; Nunes, 1997; Bursztyn \& Chacon, 2013). Esses autores ressaltam a força das redes locais de poder na conformação de práticas de mandonismo e de autoridade calcada em valores tradicionais, os quais, conforme os dados expostos acima, ainda exercem influência na juventude.

O vínculo dos candidatos com os sindicatos e os movimentos sociais é pouco valorizado pelos jovens eleitores, tanto no caso do voto para prefeito $(8,93 \%)$ como para vereador (9,66\%). O argumento principal, segundo um dos informantes, é que

\footnotetext{
os candidatos ligados a sindicatos e movimentos de bairros são importantes para resolver questões de pequeno porte, como agentes para a negociação com os prefeitos e vereadores, mas não para ocuparem cargos mais altos. Eles não têm apoio dos grandes partidos e de políticos importantes. Além disso, eles são conhecidos só pelos grupos que representam ou os bairros onde moram, sem cacife político para representar uma cidade inteira.
}

É notório que, na maioria dos casos, os candidatos vinculados aos movimentos sociais e aos sindicatos locais têm como agenda política questões como as lutas das minorias pela moradia, pela saúde, educação e pelo emprego. São, na maioria dos casos, demandas segmentadas, sem a chancela dos grandes partidos e dos cacifes políticos regionais ou locais. Trata-se da pequena política, nos termos de Gramsci (2000), ou seja, aqueles movimentos populares que, apesar de localmente relevantes, nem sempre conseguem o reconhecimento da grande política, aquela já institucionalizada pelo Estado. Essa provavelmente é uma das explicações para o baixo reconhecimento desse tipo de política na percepção dos jovens eleitores que manifestaram as opiniões acima relatadas. 
Fatores como o histórico político do candidato, as propostas escritas e o próprio partido exercem pouco peso no julgamento dos jovens. São, para eles, aspectos pouco determinantes na escolha do voto. Em relação ao histórico, é emblemático o seguinte relato:

O candidato pode ter sido um bom vereador mas não ter condições para ser prefeito, pois vereador pode se ocupar de um tema único, como meio ambiente, por exemplo, enquanto o prefeito precisa ter competência para cuidar da cidade inteira.

Quanto às propostas escritas dos candidatos, os respondentes acham pouco relevantes, "pois o que está no papel geralmente é esquecido depois da eleição, sendo difícil confiar em propostas bonitas que a gente não sabe no que vão dar". Acerca do partido, a visão dos jovens é que "os políticos trocam de partido sempre que interessa e continuam a agir do mesmo jeito no partido novo, o que mostra que o partido não importa nem pra ele mesmo". O fato de o candidato ser religioso ou jovem também significa pouco para os respondentes. Em oposição à suposta expectativa de que um candidato jovem pudesse entusiasmar o eleitorado juvenil, um dos relatos registra que "política requer experiência, tanto experiência de vida, como traquejo para lidar com os políticos veteranos e nem sempre um candidato jovem pode exercer bem o cargo".

Esses dados e esse tipo de opinião contrariam o resultado de levantamento realizado em 2012 pelo DataFolha, segundo o qual "jovens preferem políticos mais novos ou estreantes" (Bächtold, 2012). A mesma pesquisa afirma que "Freixo, Chalita, Manuela D'Ávila e Ratinho Júnior levam vantagem nessa faixa etária". Talvez o resultado da pesquisa citada se justifique porque se trata de políticos jovens muito conhecidos da população, com ampla visibilidade na mídia e com carreiras bem-sucedidas. Além disso não há nenhum "estreante" entre os nomes mencionados. Todos os citados já exerceram mandatos de vereador, deputado estadual e até mesmo de deputado federal. Portanto, o levantamento do DataFolha é questionável nesse aspecto.

Os dados relativos às Tabelas 4 e 5 chamam atenção ainda para duas questões. A primeira refere-se a uma certa tendência de personalização da política, com o foco no candidato em si e não no partido. Trata-se de algo já registrado na literatura, a exemplo de Bernard Manin (1995), que ressalta o poder da imagem pessoal dos candidatos, fruto da força simbólica do marketing eleitoral e da própria midiatização da política. Como consequência disso, o histórico do partido, suas bandeiras e até mesmo o programa do candidato perderam força diante da personalização 
das campanhas. Se o programa do partido e do candidato costumavam servir de parâmetro e referência em termos de prestação de contas, com a personalização, o voto passa ser motivado principalmente pela confiança pessoal na figura do candidato.

A segunda questão refere-se ao peso moral do voto em face das conjunturas críticas marcadas pelos escândalos de corrupção política. Aqui é oportuno registrar alguns estudos sobre o tema. Ao analisar o impacto de escândalos de corrupção no voto, Rennó (2007) ressalta que se trata de uma variável tão relevante quanto a situação da economia. Portanto,

avaliar o impacto da corrupção ao lado de outras explicações sobre o voto promove uma visão mais clara sobre quais critérios de análise retrospectiva os eleitores empregam em sua escolha eleitoral (Rennó, 2007: 263).

Na mesma linha de raciocínio, Baptista (2013) complementa que o eleitor

pode punir o candidato ou o partido em função dos escândalos de corrupção, no entanto, não se deve atribuir esse aspecto como causa única da decisão do eleitor (Baptista, 2013: 24).

Speck (2013: 151) argumenta ainda que a corrupção é uma variável ambígua na conformação da moral do voto, "dependendo do contexto político e histórico", ou seja, há um relativismo moral nas moralidades do voto, vinculada a um relativismo cultural no âmbito da cultura política. Isso significa que a moral da política "é cambiante e submetida às relações de poder, de disputa e de luta. Ela não é um código moral, universalizável, fixo, essencializado" (Villela , 2010: 163).

Em relação às qualidades pessoais dos candidatos, a honestidade é mais impor-

\section{TABELA 6}

QUAIS AS QUALIDADES PESSOAIS DOS

CANDIDATOS QUE VOCÊ MAIS LEVOU EM CONTA?

\begin{tabular}{l|c|c|}
\multicolumn{1}{|c|}{ Qualidades } & N & $\%$ \\
\hline Honestidade & 421 & 50,42 \\
\hline Competência política & 228 & 27,31 \\
\hline Capacidade de ajudar os pobres & 129 & 15,45 \\
\hline Capacidade de cumprir as promessas de campanha & 57 & 6,83 \\
\hline Outras & 0 & 0,00 \\
\hline Total* & 835 & 100,00 \\
\hline * Os informantes podiam marcar mais de uma alternativa do questionário. \\
Fonte: Elaboração própria.
\end{tabular}
tante do que a competência, o que soa contraditório em relação aos depoimentos mencionados acima, que primam pela tradição e pela experiência. Essa perspectiva é reforçada com a baixa preferência pelo item "capacidade de cumprir as promessas de campanha". O item sobre a capacidade de 
ajudar os pobres tinha como propósito avaliar se os jovens valorizavam práticas políticas assistencialistas. As respostas contrariam essa suposição, como se pode observar na Tabela 6.

Quanto à honestidade e à capacidade de cumprir promessas de campanha, pesquisa realizada com estudantes do ensino médio por Martins (2012) revela resultados similares: $36,33 \%$ consideram mais importante a honestidade e $27,66 \%$ a capacidade de executar o que foi prometido durante a campanha eleitoral. Segundo o autor, essas preferências expressam

forte tendência da visão dos estudantes para duas temáticas centrais na atualidade política brasileira, a corrupção (pelo contraponto à qualidade de honestidade) e a discrepância entre o marketing eleitoral (promessas de campanha) e a efetiva gestão dos serviços públicos durante os mandatos (Martins, 2012: 46).

O desinteresse pela campanha eleitoral chega a 70,62\%, como mostra a Tabela 7. "A campanha é uma chatice, um blá-blá insuportável", relata um dos jovens. Outro complementa que "durante a campanha, os candidatos ficam brigando entre si o tempo todo, trocando acusações, o que é muito desagradável". Além disso, "não tenho tempo nem paciência para esse teatro da campanha, é repugnante ver os candidatos se atacarem". Entre a minoria que acompanhou, a preferência é pelas redes sociais (16,36\%), pois "tem mais a ver comigo, eu posso escolher o que eu quero ver, além disso, prefiro ver os vídeos, textos e memes compartilhados pelos meus amigos". Os debates na TV despertam interesse de apenas 7,93\% desse segmento que acompanha as campanhas eleitorais. "Os debates são chatos e encenados, um teatro sem graça", revelou um dos respondentes. Outro comentou que

TABELA 7

VOCÊ ACOMPANHOU A PROPAGANDA ELEITORAL?

\begin{tabular}{|l|c|c|}
\hline \multicolumn{1}{|c|}{ Respostas } & N & $\%$ \\
\hline Acompanhei pelas redes sociais & 167 & 16,36 \\
\hline Não acompanhei & 721 & 70,62 \\
\hline Acompanhei pelos debates na TV & 81 & 7,93 \\
\hline Analisei as propostas do candidato para a cidade & 25 & 2,45 \\
\hline Acompanhei pelo rádio e a TV durante o horário eleitoral gratuito & 13 & 1,27 \\
\hline Acompanhei pela internet - portais dos partidos e dos candidatos & 12 & 1,18 \\
\hline Acompanhei por outros meios & 2 & 0,20 \\
\hline Total & 1.021 & 100,00 \\
\hline
\end{tabular}

Fonte: Elaboração própria. 
a mídia transforma o debate em show e os mediadores querem aparecer mais do que os candidatos, impondo regras sem sentido e fazendo perguntas que estimulam o confronto pessoal entre os candidatos e não o debate de ideias de fato.

Mais uma vez as propostas escritas dos candidatos não despertam o interesse dos jovens, pois "não são confiáveis", na visão deles. "Prometer é fácil, basta contratar uma equipe competente para fazer um brilhante plano de governo, mas realizar o prometido é outra estória", expressou-se outro informante.

TABELA 8

VOCÊ ACHA A ATUAÇÃO DO PREFEITO E DOS VEREADORES

DA SUA CIDADE AFETA A SUA VIDA?

\begin{tabular}{|c|c|c|}
\hline Respostas & $\mathrm{N}$ & $\%$ \\
\hline Afeta diretamente & 572 & 46,85 \\
\hline Afeta em termos & 319 & 26,13 \\
\hline Afeta muito pouco & 212 & 17,36 \\
\hline Não afeta em nada & 91 & 7,45 \\
\hline Não sei avaliar & 27 & 2,21 \\
\hline Total & 1.221 & 100,00 \\
\hline
\end{tabular}

Mesmo sem entusiasmo pelas campanhas e sem confiança nas propostas dos candidatos, 46,85\% dos jovens consideram que a atuação do prefeito e dos vereadores afeta a vida deles, como mostra a Tabela 8. Poucos são os que acham que não afeta em nada. Em suas próprias palavras, "afeta muito porque tudo depende de política, desde a coleta de lixo à limpeza das praças públicas". Outro informante escreveu que

mesmo não gostando de política e sabendo da corrupção que é, não tem como negar que são os vereadores e o prefeito que tomam as decisões mais importantes, como aumentar impostos e escolher de que forma o dinheiro público será aplicado.

O que se deduz é que a percepção do eleitorado jovem tende mais para uma visão negativa de como a atuação de prefeitos e vereadores afeta a vida dos cidadãos, como na menção ao aumento de impostos. Há ainda uma conotação autoritária dessas decisões, pois os jovens entendem que "eles tomam as decisões sozinhos". Esses dois fatores certamente são crucias para o afastamento dos jovens da política partidária, já que, na percepção deles a política é feita de modo autoritário, cujas decisões acarretam ônus para o cidadão.

Em relação aos temas que os jovens consideram mais importantes, mesmo com pouco entusiasmo pela campanha eleitoral, destaca-se em primeiro lugar o combate à corrupção política (21,30\%), como mostra a Tabela 9. "A corrupção está destruindo a nossa esperança", justificou um dos respondentes. Educação, saúde, segurança pública e mobilidade urbana aparecem na sequência, mostrando a sintonia dos jovens com os problemas brasileiros atuais, em todas as grandes e médias cida- 
des. "Todos os serviços públicos são uma calamidade, seja a educação, a saúde ou os transportes públicos", escreveu um dos informantes. Os dados mostram uma preocupação maior com os temas que integram os chamados "valores materialistas", em contraposição aos valores pós-materialistas, como meio ambiente, direitos humanos, cultura, lazer, esportes, equidade de gêneros e combate ao racismo (Ribeiro, 2008; Ribeiro, 2010; Pereira, Torres \& Barros, 2004).

Os estudos que aplicam a teoria do desenvolvimento humano de Inglehart e Welzel (2009) em países latino-americanos mostram que os problemas materiais e econômicos são mais relevantes para a população, uma vez que se trata de uma agenda de questões ainda não resolvidas. Assim, os valores pós-materialistas seriam mais expressivos nas democracias consolidadas. Certamente essa é uma explicação plausível para a baixa menção dos jovens a temas como combate ao racismo, equidade de gêneros, artes e cultura, esporte e lazer, meio ambiente.

Isso não significa que essa agenda pós-materialista não seja relevante para a juventude brasileira, até porque se trata de uma geração socializada com essa discussão, seja no espaço midiático, seja no ambiente escolar/universitário. Entretanto, a questão solicitava que os jovens mencionassem os temas prioritários na agenda política local durante a
TABELA 9

QUAIS OS TEMAS QUE VOCÊ CONSIDEROU MAIS IMPORTANTES NO DEBATE DURANTE A CAMPANHA ELEITORAL?

\begin{tabular}{|c|c|c|}
\hline Temas & $\mathrm{N}$ & $\%$ \\
\hline Combate à corrupção & 756 & 21,30 \\
\hline Educação & 543 & 15,30 \\
\hline Saúde & 521 & 14,68 \\
\hline Segurança Pública & 519 & 14,62 \\
\hline Mobilidade Urbana & 421 & 11,86 \\
\hline Direitos Humanos & 213 & 6,00 \\
\hline Trabalho e Emprego & 211 & 5,95 \\
\hline Meio Ambiente & 124 & 3,49 \\
\hline Esportes e Lazer & 78 & 2,20 \\
\hline Artes e Cultura & 77 & 2,17 \\
\hline Igualdade entre homens e mulheres & 54 & 1,52 \\
\hline Combate ao racismo & 32 & 0,90 \\
\hline Total & 3.549 & 100,00 \\
\hline
\end{tabular}

Fonte: Elaboração própria.

\section{TABELA 10}

QUAIS FORAM AS SUAS PRINCIPAIS FONTES DE INFORMAÇÃO SOBRE OS CANDIDATOS DE SUA ESCOLHA?

\begin{tabular}{|c|c|c|}
\hline Fontes & $\mathrm{N}$ & $\%$ \\
\hline Família & 721 & 34,40 \\
\hline Colegas da escola e da universidade & 319 & 15,22 \\
\hline Amigos & 311 & 14,84 \\
\hline Redes sociais & 173 & 8,25 \\
\hline Portais de notícias & 172 & 8,21 \\
\hline Televisão & 76 & 3,63 \\
\hline Jornais e revistas & 72 & 3,44 \\
\hline Coletivos e movimentos de jovens & 70 & 3,34 \\
\hline ONGs & 68 & 3,24 \\
\hline Igrejas & 63 & 3,01 \\
\hline Sindicatos & 21 & 1,00 \\
\hline Cooperativas & 18 & 0,86 \\
\hline Partidos políticos & 12 & 0,57 \\
\hline Total & 2.096 & 100,00 \\
\hline
\end{tabular}

Fonte: Elaboração própria. 
TABELA 11

NO ÂMBITO DE SUAS RELAÇÕES INTERPESSOAIS MAIS PRÓXIMAS, QUAIS AS PESSOAS QUE EXERCERAM MAIOR INFLUÊNCIA NA SUA DECISÃO DE VOTO?

\begin{tabular}{|l|c|c|}
\hline \multicolumn{1}{|c|}{ Influências } & N & 31,98 \\
\hline Meus pais e familiares & 496 & 20,83 \\
\hline Líderes estudantis e integrantes do grêmio estudantil ou centro acadêmico & 323 & 12,70 \\
\hline Dirigentes de Ongs e movimentos sociais & 197 & 12,19 \\
\hline Vizinhos e amigos & 189 & 6,32 \\
\hline Meus professores & 98 & 5,74 \\
\hline O pastor ou o padre da minha igreja & 89 & 5,03 \\
\hline Líderes comunitários & 78 & 5,03 \\
\hline Líderes sindicais & 78 & 0,19 \\
\hline Outros & 3 & 100,00 \\
\hline Total* & 1.551 & \\
\hline
\end{tabular}

* Os informantes podiam marcar mais de uma alternativa do questionário. Fonte: Elaboração própria.

campanha eleitoral. Nesse contexto, educação, saúde e mobilidade urbana certamente são mais urgentes.

As Tabelas 10 e 11 revelam a força dos suportes sociais de proximidade na formação e socialização política dos jovens, tanto em termos de fontes de informação como de influência no voto. Os vínculos familiares exercem uma relevância expressiva em ambos os casos. A família é considerada uma fonte de informação confiável sobre os candidatos $(34,40 \%)$, da mesma forma que exerce peso efetivo na decisão de voto dos jovens $(31,98 \%)$.

Os colegas da escola/universidade e os amigos também são relevantes nos dois casos.

Mais do que acreditar na TV ou na internet eu procuro conversar com os meus familiares, amigos e colegas da universidade. O que eles dizem sobre os candidatos e suas propostas, pra mim é mais importante do que o noticiário,

escreveu um dos respondentes. Os líderes estudantis e dirigentes de ONGs também são considerados relevantes para a formação da opinião dos jovens sobre os candidatos.

O noticiário político exerce pouco peso na opinião dos jovens, especialmente no caso das mídias convencionais. As redes sociais dominam as preferências dos respondentes, embora o percentual seja baixo (8,25\%). Instituições como coletivos e movimentos de jovens, ONGs, igrejas, sindicatos, cooperativas e partidos políticos servem de referência política para pequenos segmentos de jovens, com percen- 
tuais de variam de 3,34\% a 0,86. É sintomática a baixa expressividade dos partidos $(0,57 \%)$. Figuras como professores, pastor/padre, líderes comunitários e sindicais também exercem influência no voto dos jovens, como mostra a Tabela 11.

A respeito do papel político da família, os jovens destacaram que "a família é o nosso apoio maior, é a nossa bússola e nossa referência moral". Outro relato destaca que

eu discuto todas as minhas decisões com os meus pais e na política não é diferente, pois meus pais têm uma visão mais ampla dos fatos, mais experiência, pois já votaram em várias eleições, enquanto eu vou votar pela primeira vez.

Até mesmo o noticiário político é discutido com os familiares por um segmento expressivo dos jovens:

A televisão e as redes sociais transformam a política em um espetáculo, eu sinto a necessidade de ouvir meus familiares, de discutir com eles aquilo que aparece na mídia, pois eu sei que a mídia não é neutra.

Os dados acima mencionados e os depoimentos estão em sintonia com estudos sociológicos que ressaltam a importância da família para a juventude da América Latina. Segundo Bernardo Kliksberg (2006) "a família continua a ser a unidade essencial para os jovens". Complementa o autor,

várias pesquisas recentes corroboraram seu peso fundamental na afetividade, na saúde psíquica, no equilíbrio emocional, na maturidade, na inteligência emocional, na capacidade de aprendizagem e em outras áreas-chave (Kliksberg, 2006: 918).

[Essas mesmas pesquisas] indicam terminantemente o grande valor que os jovens dão ao núcleo familiar. Apesar da desconfiança de várias instituições da sociedade, a família permaneceu como seu reduto afetivo, o lugar onde podem expressar-se plenamente, dar voz a suas confidências e encontrar guias e orientação (Kliksberg, 2006: 918-919).

A mesma visão é compartilhada por Rosângela Barbiani (2007):

A família [...], quando citada nos textos, comparece como lócus do encontro das condições materiais e simbólicas de coexistência dos jovens. É a categoria que medeia o trânsito do privado-público-privado, sendo permeável tanto as convocatórias locais quanto as globais. É a família [...] o âmbito onde todos estão incluídos, onde 
se define o lugar real e imaginário de cada categoria de atores no entorno do parentesco. A família, no sentido amplo, como grupo parental, é, quiçá, a principal instituição na qual se define e se representa a condição de ser jovem, o cenário no qual se articulam todas as variáveis que a definem (Barbiani, 2007: 146).

Quanto aos líderes estudantis e os colegas da escola/universidade, os jovens chamam a atenção para a importância da experiência daqueles que já estão engajados no movimento estudantil há algum tempo e ao conhecimento dos veteranos sobre política, conforme o relato de um dos informantes:

Eu admiro os caras que se dedicam a uma causa, acreditam naquilo
e lutam pelos direitos dos demais estudantes. Eles já sabem muito
sobre o funcionamento do movimento estudantil e da política de
modo geral. São experientes e isso é muito importante. Por isso eu
valorizo a opinião de quem já está na estrada e já tem uma cami-
nhada, um aprendizado.

Outro jovem relata que a convivência na universidade

me fez aprender mais sobre política do que em sala de aula, pois os professores só estão preocupados em ministrar seu conteúdo e fazer as provas, enquanto há colegas que militam em partidos políticos e em movimentos sociais, com muito conhecimento vindo da base, do chão da experiência cotidiana. Por isso eu gosto de conversar com eles, para aprender com a experiência deles.

6. Conceito formulado por Helga Nowotny (1992) para se referir à progressiva desvalorização social do futuro em detrimento da crescente valorização do agora, entendido como um presente prolongado, ou um futuro que se realiza nos limites desse presente ampliado, como o lugar da realização dos desejos e das esperanças.

O movimento estudantil é considerado na literatura como uma "ponte" para a militância política ou mesmo para despertar os estudantes para uma postura mais crítica em relação à política institucionalizada (Barros \& Martins, 2016). Rosana Nazzari (2005) ressalta que o engajamento de um jovem se reverte tanto em aprendizado político para si próprio como também no estabelecimento de redes de engajamento, uma vez que um estudante atrai outros coetâneos para o movimento. Carmen Leccardi (2005) e Monica Franch (2011) associam a participação estudantil ao cam-

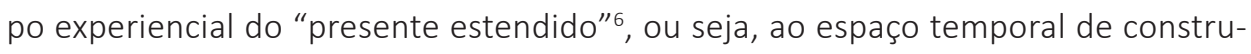
ções estratégicas de reprodução material e simbólica "em consonância com visões mais presenteístas da vida social" (Franch, 2011: 10).

Trata-se, nas palavras da autora, de uma projeção biográfica de orientação presenteísta, ou seja, um modo de vida projetado a curto prazo, "numa série de presentes sucessivos" (Franch, 2011: 12). Afinal, os jovens vivem sob a pressão do curto prazo. Segundo Luís Antonio Groppo (2004: 17), é inerente à condição juvenil essa relação com o tempo, uma vez que se trata de uma relação experimental com valores e 
estruturas sociais do presente ou atuação de ensaio, nos termos de Maria Helena Augusto (2005). Assim, a condição juvenil, como relação experimental com o presente, tende a fazer com que as juventudes valorizem mais as vivências do imediato e a espontaneidade.

Os dados e os depoimentos chamam a atenção para a importância da socialização política, pois é disso que os jovens falam nos relatos acima. É por meio da socialização que os indivíduos assimilam, aderem ou rejeitam determinados valores, conceitos e preconceitos. A socialização política refere-se ao

conjunto de experiências que, no decorrer do processo de formação da identidade social do indivíduo, contribuem particularmente para plasmar a imagem que ele tem de si mesmo em confronto com o sistema político e em relação às instituições (Oppo, 2000: 1202).

Estão incluídos nesse processo tendências cognitivas e expressivas, emoções, atitudes e comportamentos dos indivíduos perante objetos da política.

A adolescência e a juventude são consideradas cruciais na socialização política, pois trata-se do período mais relevante em termos de formação de valores. Robert Dahl é um dos expoentes na defesa da relevância da infância e da adolescência como fase basilar da socialização política. A aquisição de valores e crenças relacionados ao mundo social e à esfera da política ocorre com maior densidade nas primeiras décadas de vida, fase em que as figuras tutelares e os sistemas de transmissão de valores são mais efetivos, devido à maior receptividade dos indivíduos. Na vida adulta, os indivíduos tendem a buscar maior autonomia de pensamento e passam a recorrer às disposições e repertórios já acumulados (Dahl, 1997). A ênfase dos estudos sobre socialização política nos adolescentes e jovens se justifica ainda pela premissa de que as atitudes e os valores políticos que se desenvolvem nessa fase da vida exercem "papel significativo nas fundações psicológicas de valores políticos numa sociedade" (Baquero, 1997: 3).

Devido à relevância da adolescência e da juventude, a força da socialização política entre jovens recai principalmente em três agentes de socialização: a família, a escola e os grupos de pares. A família ${ }^{7}$

tem sido considerada desde sempre a instituição mais influente na formação da imagem que os indivíduos têm da sociedade e do seu modo de pôr-se em relação às instituições políticas. Sendo através da família que o indivíduo recebe a sua primeira e muitas vezes decisiva posição social, e sendo sob o signo de um forte envolvimento emotivo de elevado valor socializante que se de-
7. A respeito do papel da família na socialização política, é oportuno considerar a crítica de Richard Merelman (1980:

468). Para o autor, é questionável pensar numa contribuição da família para a democracia, visto que se trata de uma instituição que, embora relevante para a socialização em sentido amplo, apresenta uma estrutura interna de poder muito específica, sem analogias diretas com as instituições políticas. Enquanto a família "é uma produtora permanente de conexões emocionais", as instituições democráticas situam-se no campo das barganhas racionais dos jogos de poder. Essa crítica é relativizada por Jackson Aquino (2004: 195), para quem "o ambiente emotivo terno no interior da família é fundamental para um saudável desenvolvimento moral da criança, e o desenvolvimento moral, por sua vez, é fundamental para a capacidade de participar de debates nos quais o objetivo é menos vencer do que chegar a um compromisso. Um adulto moralmente sofisticado tem boas chances de ser um bom cidadão para a democracia". 
senvolve a interação com os membros do núcleo familiar, notadamente com os pais, julga-se que a influência familiar é também muito intensa quanto às orientações políticas fundamentais (...) As pesquisas tem encontrado correlações significativas entre as atitudes políticas dos pais e dos filhos, especialmente no que se refere à fidelidade ideológica partidária, à confiança ou ao cinismo político, à tendência à participação ou à apatia política" (Oppo, 2000: 1204).

A escola também é considerada uma agência de socialização política de grande importância para a formação da orientação política dos indivíduos.

A extensão da escolarização à quase totalidade da população dos países econômica e socialmente mais avançados, o ingresso na escola em idade cada vez mais precoce e a permanência nela cada vez mais longa fazem com que alguns pensem que a influência política da escola pode ser de igual importância, se não maior, que a família (Oppo, 2000: 1204).

Quanto aos grupos de pares ou grupos de coetâneos, os efeitos na socialização política são expressivos porque os adolescentes e jovens passam muito tempo juntos, com a sua "turma" ou sua "galera". Em alguns casos, as conversas são mais francas e intensas do que com os familiares. Eles compartilham não apenas ideias, mas estilos de comportamento e regimes de vida típicos dessa fase etária (Castro \& Matos, 2009).

O grau de insatisfação dos jovens com a situação política de sua cidade é expressivo, como mostra a Tabela 12 . Apenas $6,39 \%$ se declaram satisfeitos. A insatisfação é fruto do desencanto com a política partidária e a democracia representativa, como já ficou evidenciado em outros tópicos. Os depoimentos reforçam essa visão.

TABELA 12

EM RELAÇÃO À SITUAÇÃO POLÍTICA

DE SUA CIDADE, FINALIZADAS AS ELEIÇÕES, COMO VOCÊ SE CONSIDERA?

\begin{tabular}{|l|r|r|}
\hline \multicolumn{1}{|c|}{ Respostas } & N & $\%$ \\
\hline Nada satisfeito & 522 & 42,75 \\
\hline Pouco satisfeito & 478 & 39,15 \\
\hline Satisfeito & 78 & 6,39 \\
\hline Indiferente & 56 & 4,59 \\
\hline Não sei avaliar & 55 & 4,50 \\
\hline Completamente satisfeito & 32 & 2,62 \\
\hline Total & 1221 & 100,00 \\
\hline
\end{tabular}

Eu não tenho motivos para estar satisfeito, pois entra eleição e sai eleição e a cidade continua de mal a pior, não vejo nenhuma melhoria apesar da enxurrada de promessas durante a campanha eleitoral,

escreveu um dos jovens. Outro complementou:

Cada eleição é uma decepção. Ideias e projetos para transformar a cidade não faltam, mas acaba o mandato dos prefeitos e vereadores e nada é feito. 
Registramos mais um argumento que segue esse mesmo raciocínio:

Os políticos da minha cidade são ótimos no gogó, fazem discursos que são uma beleza, mas na prática não fazem nada para cuidar efetivamente dos problemas da cidade. A gente só lembra que tem políticos nessa cidade quando é época de campanha eleitoral. Fora disso, eles somem e não prestam contas a ninguém do que fazem ou deixam de fazer. O sumiço deve ser vergonha do povo, já que não têm nada de bom para mostrar aos eleitores.

Assim como a satisfação, o nível de confiança também é baixo nos novos prefeitos e vereadores eleitos em 2016, como mostram as Tabelas 13 e 14. As razões da desconfiança estão diretamente relacionadas com a insatisfação. Aliás os estudos sobre juventude e política sempre mostram que a insatisfação e a desconfiança são marcas constantes da percepção juvenil. No entanto, a maioria desses estudos trata da política nacional, em seu sentido amplo. Aqui o propósito foi avaliar se no âmbito local, devido à proximidade física entre os eleitores jovens e os políticos, haveria algum diferencial. Talvez não seja algo numericamente tão superior ao plano nacional, mas há um dado que pode ser uma particularidade: cerca de $20 \%$ se declarou com alguma confiança tanto no prefeito eleito como nos vereadores. Ao se somarem os que se declaram com alguma confiança e os que se dizem muito confiantes, esse número se aproxima de $25 \%$ em ambos os casos, ou seja quase um quarto dos jovens eleitores, apesar da insatisfação, manifestou confiança com os novos eleitos para administrar a cidade em que vivem.

TABELA 13

QUAL O SEU NÍVEL DE CONFIANÇA NO PREFEITO ELEITO?
TABELA 14

QUAL O SEU NÍVEL DE CONFIANÇA NOS VEREADORES ELEITOS?

\begin{tabular}{|l|c|c||c|c|c|}
\hline \multicolumn{1}{|c|}{ Respostas } & N & $\%$ & \multicolumn{2}{c|}{ Respostas } & N \\
\hline Estou com pouca confiança & 498 & 40,79 & Estou com pouca confiança & 474 & 38,82 \\
\hline Estou sem nenhuma confiança & 378 & 30,96 & Estou sem nenhuma confiança & 431 & 35,30 \\
\hline Estou com alguma confiança & 256 & 20,97 & Estou com alguma confiança & 247 & 20,23 \\
\hline Estou muito confiante & 69 & 5,65 & Estou muito confiante & 49 & 4,01 \\
\hline Não sei avaliar & 20 & 1,64 & Não sei avaliar & 20 & 1,64 \\
\hline Total & 1221 & 100,00 & TOTAL & 1221 & 100,00 \\
\hline
\end{tabular}

Vários autores (Porto, 1996; Boschi, 2004; Stoker, 2006; Dalton, 2007; Moisés, 2009) enfatizam a crise de descrédito por que passam as instituições políticas contemporâneas. Essa desconfiança nos políticos, o ceticismo em relação a instituições democráticas e a desilusão com o processo democrático chegam a ser apontadas por Dalton (2007) e Stoker (2006) como o grande desafio das democracias contem- 
8. Para um panorama desses estudos, ver Power \& Jaminson (2005); Lopes (2004); Ribeiro (2011); dentre outros. porâneas, já que é comum a todas as democracias industriais avançadas. A desconfiança é apontada em vários estudos da ciência política ${ }^{8}$ como efeito da percepção da corrupção e ênfase da mídia em informações sobre condutas inadequadas de parlamentares e figuras da vida pública (Power \& Jaminson, 2005). O desenvolvimento de uma cidadania cada vez mais crítica e vigilante também é indicado como um dos fatores do aumento da desconfiança (Ribeiro, 2011).

Em relação à juventude, levantamentos mostram até $82 \%$ de desinteresse dos jovens pela política em suas modalidades institucionalizadas (Baptista et alii, 2013). Isso se deve principalmente à recorrente associação entre política e corrupção, o que reforça o pessimismo e a descrença da juventude:

Descrentes da política, desconfiados das instituições representativas, suspeitosos em relação à organização do processo eleitoral e com poucas expectativas de serem ouvidos pelas lideranças, os jovens acabam por participar pouco da vida política. [...] Apenas $18,8 \%$ deles participam de organizações como partidos políticos, sindicatos, organizações não governamentais, associações de bairro, religiosas ou estudantis. [...] O ingresso em partidos políticos $(1,4 \%)$ ou mesmo em associações estudantis $(2,6 \%)$ é praticamente nulo (Telles \& Dias, 2010: 97).

Segundo Luís Flávio Gomes (2015),

a política [para o jovem] se transformou em algo asqueroso. Dela, ele [em geral] quer distância. A decepção da juventude é incontestável. [...] Grande parcela da juventude continua de costas para a política (Gomes, 2015).

Pesquisa realizada pelo coletivo Box 1824 (2016) mostra que 87\% dos jovens brasileiros estão insatisfeitos com a política, $81 \%$ considera que o sistema político não é confiável. Embora essas pesquisas não façam distinção entre a política nacional e a política regional/local, os indícios são de que os níveis de desconfiança parecem similares nos dois planos. Entretanto, ainda faltam estudos empíricos para aprofundar possíveis especificidades no que se refere à confiança ou desconfiança dos jovens em relação ao poder local das cidades nas quais eles residem.

\section{Conclusões}

O objetivo do estudo foi a avaliação do comportamento político dos jovens perante as eleições municipais de 2016. Nesse sentido, o percentual de abstinência foi de apenas $10 \%$ e $35,30 \%$ dos jovens votaram para os dois cargos. Os votos brancos 
$(20,63 \%)$ e nulos $(20,23 \%)$ somam 40,86\%, mas apresentam justificativas diferentes. Os brancos foram basicamente "por falta de opção", ou seja, os candidatos não agradavam aos jovens. Os nulos, por sua vez, foram motivados por protesto e contestação, isto é, como expressão de insatisfação com os candidatos que estavam na disputa eleitoral. Somados os que votaram para os dois cargos e os que votaram em branco e nulo temos $74,16 \%$, o que indica que não houve apatia dos jovens nas eleições municipais de 2016. Afinal, as justificativas apresentadas para votar em branco e nulo também são formas ativas de se posicionar politicamente.

A honestidade é a característica mais importante que um político deve ter na opinião dos jovens. Por essa razão, um dos motivadores para a escolha tanto do candidato a vereador como a prefeito foi o fato de o candidato não estar envolvido em denúncias judiciais. Esse tipo de percepção também revela uma postura ativa dos jovens em relação à política municipal. Talvez por isso os jovens sejam considerados afastados da política atualmente, visto que nos últimos anos as denúncias de corrupção contra os partidos e os políticos eleitos são muito expressivas. Talvez por essa razão a honestidade tenha sido apontada pelos jovens como mais relevante do que a competência política.

O elevado envolvimento de políticos com situações consideradas suspeitas do ponto de vista ético pode ser também uma das explicações para o baixo interesse dos jovens pela campanha eleitoral por seus meios institucionais, como o horário eleitoral gratuito no rádio e na TV e os debates televisionados entre os candidatos. Cerca de $70 \%$ dos jovens declararam não ter acompanhado a propaganda eleitoral e apenas 7,93\% assistiram aos debates transmitidos. Entretanto, os jovens mostraram interesse em discutir política preferencialmente com seus familiares, amigos da escola/universidade e também pelas redes sociais, devido à presença de amigos nessas ferramentas digitais. Isso mostra a importância que os jovens atribuem às relações interpessoais, à confiança nos familiares e amigos. As respostas dos jovens chamam a atenção para a força que ainda exercem como agentes de socialização política a família, a escola/universidade e os grupos de pares. Os líderes estudantis, os dirigentes de ONGs e movimentos sociais também exercem influência expressiva na decisão de voto dos jovens.

Os dados revelam ainda um perfil conservador dos jovens quando se trata de política, com a valorização da tradição na política local. Isso aparece, por exemplo, no elevado percentual de respostas que valoriza a família dos candidatos, ou seja, quando o candidato é oriundo de uma família que já atua na política local há muito tempo. Os jovens pesquisados também consideram importante o apoio de partidos e políticos reconhecidos na região. Dessa forma, os respondentes não consideram importante o 
lançamento de candidaturas independentes ou a entrada de jovens na disputa política local. Os depoimentos chamam a atenção para elementos como a experiência, os vínculos com políticos dos "escalões superiores" e a proximidade dos candidatos com os políticos tradicionais. Um candidato jovem, para representar os próprios jovens, não parece ser uma reivindicação dos eleitores que responderam ao questionário. Eles valorizam mais a experiência política e a representação de ideias.

Outro dado relevante é que os jovens estão preocupados com uma agenda política considerada materialista, conforme vimos no tópico sobre a análise dos dados. Os temas da chamada agenda pós-materialista apresentam percentuais pouco expressivos. Isso certamente porque a maioria das cidades brasileiras ainda enfrenta dificuldades para resolver problemas materiais básicos como saúde, educação, transportes públicos, coleta e tratamento do lixo, desemprego e outros problemas similares.

A política partidária não se mostra atraente para os jovens, mesmo quando se trata da cidade onde eles vivem. Os depoimentos mencionados ao longo do texto mostram uma série de razões pelas quais a política partidária não é atrativa para eles. Os jovens são críticos e reativos em relação à política partidária. Como vimos, quando os candidatos não thes agradam, preferem votar em branco. Como estão insatisfeitos com a política local preferem votar nulo, como forma de protesto, ou seja, como reação a uma situação que não condiz com suas expectativas. Por outro lado, observa-se um paradoxo: os jovens manifestam insatisfação e por isso votam como protesto, porém, a pesquisa mostra que há registro de razões de escolha do voto que se situam na esfera tradicional, a exemplo do voto em candidatos provenientes de famílias que já atuam na política local.

\section{Referências}

ABRAMO, H.; VENTURI, G. Juventude, política e cultura. Teoria e Debate, n. 45, p. $1-4,2000$.

ACSELRAD, Henri. Discursos da sustentabilidade urbana. Revista Brasileira de Estudos Urbanos e Regionais, v. 1, n. 1, p. 79-90, 2011.

AQUINO, Jackson Alves. Socialização e política. Sociedade e Cultura, v. 7, n. 2, p. 191-205, 2004.

AUGUSTO, Maria Helena Oliva. Retomada de um legado: Marialice Foracchi e a sociologia da juventude. Tempo Social, v. 17, n. 2, p.11-33, 2005 
AUGUSTO, Nuno Miguel. A juventude e a(s) política(s): desinstitucionalização e individualização. Revista Crítica de Ciências Sociais, n. 81, p. 155-177, 2008.

BÄCHTOLD, Felipe. Jovens preferem políticos mais novos ou estreantes. Folha online, 30 Set. 2012. Disponível em: <http://www1.folha.uol.com.br/fsp/poder/69232-jovens-preferem-politicos-mais-novos-ou-estreantes.shtml>. Consultado em: 11 Nov. 2016.

BAPTISTA, Érica Anita. Internet e escândalos políticos: a corrupção e as eleições municipais de 2012. Anais do V Congresso da Compolítica. Curitiba, 8 a 10 de maio de 2013. Disponível em: <http://www.compolitica.org/home/wp-content/ uploads/2013/05/GT04-Internet-e-politica-EricaAnitaBaptista.pdf>. Acesso em: 29 Jan. 18.

BAPTISTA, Érica Anita et alii. Jovens eleitores e novas tecnologias: percepções da política e participação. Revista do Legislativo, v. 5, n. 1, p. 124-132, Belo Horizonte, 2013

BAQUERO, Marcello. Democracia, cultura e comportamento político: uma análise da situação brasileira. Rio de Janeiro: Relume Dumará, 2002.

- O papel dos adolescentes no processo de construção democrática no Brasil: um estudo preliminar de socialização política. Cadernos de Ciência Política, v. 1, n. 8, p. 23-37, 1997.

BAQUERO, Marcello; CREMONESE, Dejalma. Eleições municipais 2008: uma análise do comportamento eleitoral brasileiro. Ijuí (RS): Editora Unijuí, 2009.

BARBIANI, Rosângela. Mapeando o discurso teórico latino-americano sobre juventude(s): a unidade na diversidade. Textos \& Contextos, v. 6, n. 1, p. 138-153, 2007.

BARDIN, Laurence. Análise de conteúdo. Lisboa: Edições 70, 2009.

BARREIRA, César. Os pactos na cena política cearense: passado e presente. Revista do Instituto de Estudos Brasileiros, n. 40, p. 31-49, 1996.

BARREIRA, César; BARREIRA, Irlys Alencar F. Campos de ajuda e modos de pertencimento: um mapa moral da representação política em campanha eleitoral. Horizontes Antropológicos, v. 18, n. 37, p. 307-335, 2012.

BARROS, Antonio Teixeira de; MARTINS, Lúcio Meireles. Juventude e comunicação política: estudo sobre os egressos do Parlamento Jovem Brasileiro. Ixvii Congresso de Ciência da Comunicação na Região Centro-Oeste, 2016, Goiânia. Anais... Goiânia: PUC, 2016. Disponível em: <http://portalintercom.org.br/anais/centrooeste2016/ resumos/R51-0281-1.pdf>. Acesso em: 13 Nov. 2016. 
BOGHOSSIAN, Cynthia Ozon; MINAYO, Maria Cecília de Souza. Revisão sistemática sobre juventude e participação nos últimos 10 anos. Saúde e Sociedade, v. 18, n. 3, p. 411-423, 2009.

BORBA, Julian. Cultura política, ideologia e comportamento eleitoral: alguns apontamentos teóricos sobre o caso brasileiro. Opinião Pública, v. 11, n. 1, p. 147-168, 2005

BOSCHI, R. Instituições políticas, reformas estruturais e cidadania: dilemas da democracia no Brasil. Anais do Seminário Internacional sobre Democracia na América Latina. Santiago (CL), 2004.

BOURDIEU, Pierre. A juventude é apenas uma palavra. In: BOURDIEU, Pierre. Questões de sociologia, p. 112-121. Rio de Janeiro: Marco Zero, 1983.

BOX 1824. O sonho brasileiro da política. 20-16. Disponível em: ,http://pt.slideshare.net/cmayumi/sonho-brasileiro-da-poltica-verso-completa>. Consultado em: 30 Set. 2016

BURSZTYN, Marcel; CHACON, Suely Salgueiro. Ligações perigosas: proteção social e clientelismo no Semiárido Nordestino. Estudos Sociedade e Agricultura, n. 2, p. 30-61, 2013

CARREIRÃO, Yan de Souza. "A decisão do voto nas eleições presidenciais no Brasil (1989 a 1998): a importância do voto por avaliação de desempenho", 2000.

CASTRO, Lucia Rabello de. Participação política e juventude: do mal-estar à responsabilização frente ao destino comum. Revista Sociologia Política, Curitiba, v. 16, n. 30, p. 253-268, 2008.

CASTRO, M. M. O comportamento eleitoral no Brasil: diagnóstico e interpretações. Revista Teoria \& Sociedade, n. 1, p. 126-168, 1997.

- Sujeito e estruturas do comportamento eleitoral. Revista Brasileira de Ciências Sociais, n. 20, p. 7-19, 1992.

CASTRO, Lucia Rabello de. Juventude e socialização política: atualizando o debate. Psicologia: Teoria e Pesquisa, v. 25, n. 4, p. 479-487, 2009.

CASTRO, Lucia Rabello; MATTOS, Amana Rocha. O que é que a política tem a ver com a transformação de si? Considerações sobre a acção política a partir da juventude. Análise Social, v. 44, n. 193, p. 793-823, 2009. 
COSTA, Andressa Liegi Vieira. Desconfiança e desinteresse político no sul do Brasil: percepções da juventude em relação à política. Anais do / Seminário Internacional de Ciência Política, Porto Alegre, 9-11 de setembro de 2015.

COSTA, Homero de Oliveira. Crise dos partidos e as transformações dos governos representativos. Cronos, v. 11, n. 1, p. 274, 2016.

COSTA, João Bosco Araújo. A ressignificação do local: o imaginário político brasileiro pós-80. São Paulo em Perspectiva, v. 10, p. 103-118, 1996.

COLEN, M. C. L. As covariantes da confiança política na América Latina. Opinião Pública, v. 16, n. 1, p. 1-27, 2010.

DALTON, R. J. Democratic challenges, democratic choices: the erosion of political support in advanced industrial democracies. New York: Oxford University Press, 2007.

DAHL, Robert A. Development and democratic culture. Consolidating the Third Wave Democracies. Baltinore (MD): Johns Hospkins, 1997.

DAYRELL, Juarez; MOREIRA, Maria Ignez Costa; STENGEL, Márcia. Juventude contemporâneas: um mosaico de possibilidades. Simpósio Internacional sobre Juventude Brasileira. Belo Horizonte: Editora PUC-Minas, 2011.

DEWES, João Osvaldo. Amostragem em bola de neve e Respondent-Driven Sampling: uma descrição dos métodos. Porto Alegre: Universidade Federal do Rio Grande do Sul; Instituto de Matemática; Departamento de Estatística; Curso de Pós-Graduação em Estatística, 2013.

DOWBOR, Ladislau. O que é poder local. São Paulo: Brasiliense, 2017.

DURÁN, Paulo Renato Flores. Juventude, cidadania crítica e confiança política. Dissertação (Mestrado em Ciências Sociais) - Pontifícia Universidade Católica (PUC-Rio), Rio de Janeiro, Rio de Janeiro, 2009.

ENNE, Ana Lucia. Juventude como espírito do tempo, faixa etária e estilo de vida: processos constitutivos de uma categoria-chave da modernidade. Comunicação Mídia e Consumo, v. 7, n. 20, p. 13-35, 2011.

ESPOSITO, Ivan; LOURENÇO, Iolando. Brancos, nulos e abstenções superam votos de eleitos no Rio, BH e Porto Alegre. Carta Capital Online, 31 Out. 2016. Disponível em: $<$ https://www.cartacapital.com.br/politica/brancos-nulos-e-abstencoes-superam-votos-de-eleitos-no-rio-bh-e-porto-alegre>. Consultado em: 26 Jan. 2018.

FIGUEIREDO, M. A decisão do voto: democracia e racionalidade. São Paulo: Sumaré 1991. 
FLORENTINO, Renata. Democracia liberal: uma novidade já desbotada entre jovens. Opinião Pública, v. 14, n. 1, p. 205-235, 2008.

FISICHIELLA, Domenico. Comportamento eleitoral. In: BOBBIO, N.; MATTEUCCI, N.; PASQUINO, G. (Orgs.). Dicionário de política, p.189-192. Brasília: Editora UnB, 1992.

FISCHER, Tânia. Poder local: um tema em análise. Revista de Administração Pública, v. 4, p. 105-113, 1992.

FORACCHI, M. M. O estudante e a transformação da sociedade brasileira. São Paulo: Companhia Editora Nacional, 1965.

FRANCH, Monica. Como será o Amanhã? Juventude, exclusão social e construção simbólica do futuro no Grande Recife. Anais do XI Congresso Luso Afro Brasileiro de Ciências Sociais. Diversidades e (Des)igualdades. Salvador: Universidade Federal da Bahia, 2011.

GALHARDI, Raul. Por que os jovens estão se afastando do PT? Revista Fórum, n. 7, Jun. 2015. Disponível em: <http://www.revistaFórum.com.br/2015/06/07/porque-os-jovens-estao-se-afastando-do-pt/>. Consultado em: 05 Out. 2016.

GOHN, Maria da Glória. Os jovens e as praças dos indignados: territórios de cidadania. Revista Brasileira de Sociologia, v. 1, n. 2, p. 205-221, Jul./Dez. 2013.

GOMES, Luiz Flávio. Juventude decepcionada: Brasil é dos políticos velhos (e velhacos). JusBrasil, 28 Jun. 2015. Disponível em: <http://professorlfg.jusbrasil.com.br/ artigos/203494959/juventude-decepcionada-brasil-e-dos-politicos-velhos-e-velhacos>. Consultado em: 30 Set. 16.

GRAMSCI, A. Cadernos do cárcere. Rio de Janeiro: Civilização Brasileira, 2000.

GROPPO, Luís Antonio. Dialética das juventudes modernas e contemporâneas. Revista de Educação do Cogeime, v. 13, n. 25, p. 9-22, 2004.

HORI, Jorge. Por que muitos jovens ainda apoiam o PT? "Esquerdas e direitas ladras". Jornal da Cidade online, 29 Mar. 2016. Disponível em: <http://www.jornaldacidadeonline.com.br/noticias/2403/por-que-muitos-jovens-ainda-apoiam-o-pt-e39esquerdas-e-direitas-ladrase39\#>. Consultado em: 05 Out. 2016.

INGLEHART, R.; WELZEL, C. Modernization, cultural change, and democracy: the human development sequence. New York: Cambridge University Press, 2009.

KLIKSBERG, Bernardo. O contexto da juventude na América Latina e no Caribe: as grandes interrogações. Revista de Administração Pública, v. 40, n. 5, p. 909-942, 2006. 
LECCARDI, Carmen. Por um novo significado do futuro. Tempo Social, v. 17, n. 2, p. 35-57, 2006.

- O conceito de geração nas teorias sobre juventude. Sociedade e Estado, v. 25, n. 2, p. 185-204, 2005.

LOPES, D. M. N. N. Para pensar a confiança e a cultura política na América Latina. Opinião Pública, v. 10, n. 1, p. 162-187, 2004,

INGLEHART, Ronald; WELZEL, Christian. Modernização, mudança cultural e democracia: a sequência do desenvolvimento humano. São Paulo: Francis, 2009.

MAYORGA, C.; CASTRO, L. R.; PRADO, M. A. M. Juventude e a experiência da política no contemporâneo. Rio de Janeiro: Contra Capa Editora, 2012.

MALFITANO, Ana Paula Serrata. Juventudes e contemporaneidade: entre a autonomia e a tutela. Etnográfica, v. 15, n. 3, p. 523-542, Lisboa, 2011.

MANFREDA, Katija, Losar; VEHOVAR, Vasja. Internet Survey. In: LEEUW, Edith Desirée; HOX, J. J.; DILLMAN, Don A. (Eds). International handbook of survey methodology, p. 264-283. London: Taylor \& Francis, 2008.

MANIN, Bernard. As metamorfoses do governo representativo. Revista Brasileira de Ciências Sociais, v. 10, n. 29, p. 5-34, 1995.

MANNHEIM, Karl. O problema sociológico das gerações. In: FORACCHI, M. M. (Org.). Karl Mannheim: Sociologia. São Paulo: Ática, 1982.

- O problema da juventude na sociedade moderna. In: MANNHEIM, Karl. Sociologia da Juventude, I. Rio de Janeiro: Zahar Editores, 1968.

MARTINS, Lúcio Meireles. Educomunicação para a democracia: o programa Plenarinho e o nível de letramento político infanto-juvenil. Monografia - Programa de Pós-Graduação do Centro de Formação, Treinamento e Aperfeiçoamento da Câmara dos Deputados (Cefor). Brasília: Câmara dos Deputados, 2012.

MARTINS, José de Souza. A sociedade vista do abismo: novos estudos sobre exclusão, pobreza e classes sociais. Petrópolis: Vozes, 2003.

O poder do atraso: ensaios de sociologia da história lenta. São Paulo: Hucitec, 1999.

MERELMAN, Richard M. The family and political socialization: toward a theory of exchange. The Journal of Politics, n. 42, p. 461-486, 1980. 
MIGUEL, Luís Felipe. Capital político e carreira eleitoral: algumas variáveis na eleição para o Congresso Nacional brasileiro. Revista de Sociologia e Política, n. 20, p. 115134, 2003.

MILBRATH, Lester W.; GOEL, M. L. Political participation: how and why do people get involved in politics? Chicago: Rand McNally College Pub. Co., 1977.

MISCHE, Ann. De estudantes a cidadãos: redes de jovens e participação política. Revista Brasileira de Educação, n. 6, p. 134-150, Set./Dez. 1997.

MOISÉS, J. A. Democracia e desconfiança de instituições democráticas. Edição do autor, 2009.

NAZZARI, Rosana Katia. Capital social e socialização política dos jovens no Brasil. Educação Unisinos, v. 9, n. 2, p. 145-154, 2005.

NOWOTNY, Helga. Time and social theory: towards a social theory of time. Time \& Society, v. 1, p. 421-54, 1992.

NUNES, Edson Oliveira. A gramática política do Brasil: clientelismo e insulamento burocrático. Rio de Janeiro: Zahar, 1997.

OPPO, A. Socialização política. In: BOBBIO, N.; MATTEUCCI, N.; PASQUINO, G. (Orgs.). Dicionário de política, p. 1202-1206. Brasília: Editora da UnB, 2000.

PEREIRA, Alexandre Barbosa. Muitas palavras: a discussão recente sobre juventude nas ciências sociais. Ponto Urbe, v. 1, n. 1, 2007. Disponível em: <http://pontourbe. revues.org/1203>. Consultado em: 21 Mar. 2015

PEREIRA, Cícero; TORRES, Ana Raquel Rosas; BARROS, Thaís S. Sistemas de valores e atitudes democráticas de estudantes universitários. Psicologia: Teoria e Pesquisa, v. 20, n. 1, p. 01-10, 2004.

PORTO, M. A crise de confiança política e suas instituições: os mídias e a legitimidade da democracia. In: BAQUERO, Marcello (Org.). Condicionantes da consolidação democrática: ética, mídia e cultura política. Porto Alegre: Editora UFRGS, 1996.

POWER, T. J.; JAMINSON, G. D. Desconfiança política na América Latina. Opinião Pública,v. 11, n. 1, p. 64-93, Mar. 2005.

RADMANN, E. R. O eleitor brasileiro: uma análise do comportamento eleitoral. Dissertação (Mestrado em Ciência Política) - Universidade Federal do Rio Grande do Sul, Porto Alegre, 2001. 
RENNÓ, Lucio R. Escândalos e voto: as eleições presidenciais brasileiras de 2006. Opinião Pública, v. 13, n. 2, p. 260-282, 2007.

RIBEIRO, Ednaldo Aparecido. Participação política e juventude: mudanças no padrão de relacionamento entre os cidadãos e a política. Em Debate, v. 4, n. 8, p. 26-34, Belo Horizonte, Nov. 2012.

- Confiança política na América Latina: evolução recente e determinantes individuais. Revista de Sociologia e Política, v. 19, n. 39, p. 167-182, 2011.

- Valores pós-materialistas e adesão normativa à democracia entre os brasileiros. Debates, v. 2, n. 2, p. 103-133, 2008.

RIBEIRO, Ednaldo; BORBA, Julian. Participação e pós-materialismo na América Latina. Opinião Pública, v.16, n. 1, p.28-64, 2010.

RIBEIRO, Eliane; LANES, Patrícia; CARRANO, Paulo. Diversidade de perfis caracteriza as juventudes brasileiras. Rio de Janeiro: Ibase, 2006. Disponível em: <http://www. ibase.br/userimages/ibasenet_dv30_indicadores.pdf>. Acesso em: 30 Jun. 2014.

RIBEIRO, Guilherme Wagner. Informação, aprendizagem e inovação nas Câmaras Municipais de Minas Gerais. Tese (Doutorado em Ciências Sociais) - Pontifícia Universidade Católica de Minas Gerais, Belo Horizonte, Minas Gerais, 2010.

SALVADOR, João Pedro Pitombo de. Parentes e padrinhos fortes garantem mais recursos para a campanha de candidatos. Folhaonline, 21 Set. 2016. Disponível em: <http://www1.folha.uol.com.br/poder/eleicoes-2016/2016/09/1815293-parentes-e-padrinhos-fortes-garantem-mais-recursos-para-a-campanha-de-candidatos. html>. Consultado em: 05 Nov. 2016.

SANDOVAL, Salvador A. M. O comportamento político como campo interdisciplinar de conhecimento: a reaproximação da sociologia e da psicologia social. In CAMINO, L.; LHULLIER, L.; SANDOVAL, S. (Orgs.). Estudos sobre comportamento político, p. 13-24. Florianópolis: Letras Contemporâneas, 1997.

SILVA, Márcia. Poder local: conceito e exemplos de estudos no Brasil. Sociedade \& Natureza, v. 20, n. 2, p. 69-78, 2008.

SPECK, Bruno Wilhelm. A compra de votos: uma aproximação empírica. Opinião Pública, v. 9, n. 1, p. 148-169, 2003. 
SPÓSITO, Marilia Pontes; SILVA, Hamilton Harley de Carvalho; SOUZA, Nilson Alves de. Juventude e poder local: um balanço de iniciativas públicas voltadas para jovens em municípios de regiões metropolitanas. Revista Brasileira de Educação, v. 11, n. 32, p. 238-257, 2006.

STOKER, G. Why politics matters: making democracy work. Basingstoke (UK): Palgrave Macmillan, 2006.

TAPSCOTT, Don. Grown up digital: how the netgeneration is changing your world. New York: McGraw-Hill, 2008.

TEIXEIRA COELHO, José. Cultura e cultura política dos jovens. Revista USP, n. 32, p. 156-165, 1997.

TELLES, Helcimara de S. e DIAS, Mariana. Condutas políticas, valores e voto dos eleitores jovens de Belo Horizonte. Revista do Legislativo. n. 43, p. 82-102, Belo Horizonte, 2010.

TRIBUNAL SUPERIOR ELEITORAL (TSE). Estatísticas eleitorais. Brasília: TSE, 2016. Disponível em: <http://www.tse.jus.br/eleicoes/estatisticas/estatisticas-eleitorais>. Consultado em: 19 Nov. 2018.

VAINER, Carlos Bernardo. As escalas do poder e o poder das escalas: o que pode o poder local. Cadernos IPPUR, v. 15, n. 2, p. 13-32, Rio de Janeiro, 2002.

VILLELA, Jorge Mattar. Moral da política e antropologia das relações de poder no sertão de Pernambuco. Lua Nova, n. 79, p. 163-199, 2010.

VINUTO, Juliana. A amostragem em bola de neve na pesquisa qualitativa: um debate em aberto. Temáticas, v. 22, n. 44, p. 203-220, 2014.

ZITKOSKI, Jaime José; HAMMES, Lúcio Jorge. Juventude, educação e cidadania: os desafios da participação social e política. Debates, v. 8. n. 2, p. 119-139, Maio/Ago. 2014. 